\title{
カカオ豆の香りがチョコレート嗜好に及ぼす影響
}

\author{
星野 亜由美 ${ }^{1)}$, 石川 華衣 ${ }^{2)}$, 岡田 綾 ${ }^{2)}$, 飯田 文子 ${ }^{2)}$ \\ ${ }^{1)}$ 兵庫教育大学大学院 \\ ${ }^{2)}$ 日本女子大学家政学部食物学科
}

\section{Effect of cacao beans aroma on taste preferences for bitter chocolate}

\author{
Ayumi Hoshino ${ }^{1)}$, Kai IshikawA ${ }^{2)}$, Aya OKadA ${ }^{2)}$, Fumiko IIdA ${ }^{2)}$ \\ ${ }^{1)}$ Hyogo University of Teacher Education \\ ${ }^{2)}$ Japan Women's University
}

\begin{abstract}
Investigation of the effect of aroma on the taste characteristics of three bitter chocolates, formulated from different cacao bean varieties (harvested from Ghana, Venezuela, and Ecuador). Sensory evaluations were given scores by 95 panelists wearing or not wearing nose clips. A questionnaire survey was also carried out. Twentysix panelists showed changed preferences for chocolate in sensory tests while wearing a nose clip using the TDS (Temporal Dominance of Sensations) method. The scoring results showed the sensation of taste to be more sensitive when not wearing a nose clip than when wearing one, and that greater taste intensity was experienced without a nose clip. The TDS method revealed the key aroma characteristics: the Ghanaian chocolate had a "sweet nut" and "honey" taste, the Venezuelan variety had a "roasted nuts" flavor, and the Ecuadorian variety had as "floral" and "fruity" taste.

The questionnaire survey showed the most important item to be "Taste" $(80.0 \%)$, followed by "Aroma". The fact that $49.5 \%$ of subjects showed different preferences for chocolate types while wearing the nose clip demonstrates that the aroma of chocolates affects taste preference. Aroma is therefore an important characteristic in the sensory evaluation of chocolate.
\end{abstract}

(Received 21 June 2019, Accepted 15 November 2019)

Keywords: TDS (Temporal Dominance of Sensations) method TDS 法, Score method 採点法, flavor 香り, chocolate チョコレート, cacao beans カカオ豆, preference 嗜好

\section{1. 緒言}

食べ物の状態からみたおいしさの要因には, 化学的 要因, 物理的要因があり, われわれは異なる感覚器官 (視覚, 聴覚, 嗅覚, 触覚, 味覚) によってそれらを とらえ，食品を評価している。 また，さらに近年では， 異なる感覚間の相互作用が注目されている，嗅覚と味 覚に関する相互作用では, White \& Prescott（2007）が, スクロース溶液, クエン酸溶液をイチゴ, グレープフ ルーツそれぞれの嗅覚刺激条件下で対象者に提示した ところ, 一致する感覚刺激であった場合に比べ, 異な る刺激条件下では，味を答えるまでの反応時間が長く

著者連絡先 iida-fu@fc.jwu.ac.jp
なることを報告した，鳴海他（2010）は，バニラクッ キーにおいて, 喫食時の視覚刺激, 嗅覚刺激を変化さ せることで, 対象者の 8 割が, 味が変化したと評価す ることを報告した．Kakutani et al.（2017）は，呼吸と 連動した後鼻腔経路嗅覚刺激により, 甘味が増強され ることを報告した。 さらに, 嗅覚と触覚との関連も検 討されており, 西野他 (2014) は, 香りが感触に与え る効果を検討し, 香りの種類に依存して嗅覚情報が, 硬さ，ざらつきといった異なる感触の次元に影響する ことを明らかにした，これらのことから，官能評価に おいても味や香り単独ではなく, 香りが味に与える影 響についても検討することが重要である.

チョコレートの食味特性は, 原料, ロースト条件 
等によって変化する (Hoskin, 1994).8か国14種 のカカオ豆を用いたチョコレートに拈いて, Jinap et al.（1995）は pH が中間であるガーナ, ナイジェリア のフレーバースコアが高く, pH の低いカカオ豆では オフフレーバーが知覚されたことを報告した。ささらに, Glazier \& Dimick（2000）は, 産地の異なるカカオ豆 の香り特性をガスクロマトグラフィー分析と官能評価 により検討し，ニブ焙煎中の揮発性物質と官能評価項 目との間に関連がみられたことを報告した。また, わ れわれは, チョコレートの掞いしさに関連する因子を 検討するために, これまで, 油脂含量および組成の違 い, カカオ豆産地の違いなどに着目し研究を行った. それにより, 油脂含量 30〜 40\%のチョコレートや, 特にアクラ産, カレネロ産, アリバ産のチョコレート が好まれたことを報告した（飯田他，2007；葛西他， 2007)。これらの報告はいずれも静的官能評価を使用 したものであるが, 近年, 食品を動的に計測する手法 として, Pineau et al. (2009) によって提案されたTDS (Temporal Dominance of Sensations) 法が着目されてい る. この手法は複数の感覚特性の中で最も強い印象を もつ属性の時間的変化を測定する手法であり, チーズ パイや, ソーセージなどの食品において報告されてい る (Marcano et al., 2015; Braghieri et al., 2016). われわ れは, カカ才豆産地の異なる三種のチョコレートにお いて, 静的採点法に加え動的 TDS 法を用いることで, 対象者の嗜好に関するより詳細な味の経時的要因を明 らかにできたことを報告した（石川他，2019）。この 研究では, ノーズクリップを用い, レトロネーザルア ロマの関与を除外した条件下で詳細な味の識別を行っ た。しかしながら, 先述の通り食品中の香りは味覚を はじめとする他の感覚に影響する可能性が示唆され, チョコレートの味嗜好に与えるレトロネーザルアロマ の影響を明確にするためには, ノーズクリップ脱着そ れぞれの条件下での官能評価を実施するとともに，レ トロネーザルアロマの特徵を検討することが望まれる．

そこで本研究では, 静的官能評価として採点法, 動 的官能評価として TDS 法を用いることで, チョコレー トの香りの経時的変化の特徵と, 香りがチョコレート 嗜好に与える影響について検討することを目的とした．

\section{2. 方法}

\section{2-1. 試料および調製方法}

試料は, 先行研究 (葛西他, 2007) に扔いて「香り」, 「味」,「テクスチャー」が総合して好まれた, アクラ
（ガーナ）産, カレネロ (ベネズエラ）産, アリバ（エ クアドル）産のカカオ豆を用いたシングルビーンズ チョコレートとした. チョコレートの調製方法は, 先 行研究 (飯田他, 2007 ; 石川他, 2019, 前揭) を参照 されたい. チョコレートの形状は, 一口で食せる量と するため, 1 辺約 $1 \mathrm{~cm}$ の立方体様 $(2 \mathrm{~g})$ の形状とした.

\section{2-2. 項目の選定と訓練}

パネリストは研究室訓練パネル 13 名（22２3 歳と 教員 2 名）と訓練を行っていない一般の消費者の代表 である女子大学生 82 名 (18 22 歳) (以下, 学生パ ネル）の計 95 名を対象とした。訓練パネルにおいて, 官能評価を行うにあたり，以下，1）～4）の訓練を実 施した。

1）五味識別訓練，2）産地の異なるカカオ豆を使用 した 22 種シングルビーンズチョコレートからの言葉 だし，3）チョコレート中に含まれる香り訓練，4）市 販チョコレートを用いた官能評価訓練. 実施方法は 先行研究と同様である（飯田他, 2018). なお, 学生 パネルは食物学科に在籍する $1 \sim 4$ 年次の学生のうち, 特にチョコレートや食味評価への関心が高い者を募っ た.

\section{2-3. 官能評価}

上記訓練を施した訓練パネル，および訓練をしてい ない学生パネルに対して, カカオ豆の異なる 3 種の試 料について, 以下の官能評価を行った. 官能評価は, 従来の静的採点法 (以下, 採点法と略す) と Temporal Dominance of Sensations 法（TDS 法）の2つの手法を 用い, 採点法においては, レトロネーザルアロマが味 に及ぼす影響を検討するため, ノーズクリップ脱着そ れぞれの条件下での測定を行った.

採点法は, 従来の先行研究と同様に, チョコレート の全体的な食味特性を評価するために実施した。 -3 から+3の 7 段階尺度とし, 項目は先行研究を参考と した（飯田他, 2018, 前揭). すなわち, テクスチャー に関する項目として「口どけ」,「口ざわり」の 2 項目, 味に関する項目として「甘味」,「酸味」,「苦味」,「渋 味」,「こく」, 「後味の強さ」の 6 項目, フレーバーに 関する項目として「花のような香り」,「はちみつのよ うな香り」,「ナッッのような香り」の 3 項目, 「総合 評価」の計 12 項目とした。味については+3 強い $\Leftrightarrow$ -3 弱い, 総合評価は +3 良い $\Leftrightarrow-3$ 悪いで評価し, フ レーバーに関する項目はノーズクリップなしの条件下 のみとした．採点法の用紙の最後に， 3 種のうち最も 好きなチョコレートを記入する欄を設けた。 
Table 1 香りの好きなチョコレートに多く出現し た用語

\begin{tabular}{lcr}
\hline \multicolumn{1}{c}{ 用語 } & 出現数 & $(\%)^{\mathrm{a}}$ \\
\hline フルーツ & 17 & $(15.4)$ \\
ナッツ & 13 & $(11.7)$ \\
香ばしい & 12 & $(10.8)$ \\
はちみつ & 6 & $(5.4)$ \\
花 & 6 & $(5.4)$ \\
コーヒー & 6 & $(5.4)$ \\
スパイス & 4 & $(3.6)$ \\
炭 & 4 & $(3.6)$ \\
ココア & 3 & $(2.7)$ \\
酸っぱい & 3 & $(2.7)$ \\
木 & 3 & $(2.7)$ \\
爽やか & 3 & $(2.7)$ \\
その他 & 31 & $(27.9)$ \\
\hline
\end{tabular}

$n=13$ (訓練パネル)

$\mathrm{a}$ ：全用語出現数 111 語に占める割合. 太字は TDS 法に 用いた用語を示す.

TDS 法は, 従来の採点法よりも詳細な香り特性を 明らかとすることを目的とし，導入した，TDS 法は， 種々なモダリティを同時に評価できる測定法である が, Rodrigues et al. (2018) は, チーズのテクスチャー と味を同時評価する検討を行い，異なる2つのモダリ ティを同時評価することは困難であったことを報告し ている. そのため, 本研究においては, 香りのみを評 価対象とした．項目の選定においては Table 1 に示し た通り, 事前訓練で用いた 22 種シングルビーンズチョ コレートの言葉出しの中で, 特に香りが好ましいと評 価されたチョコレート 5 種の出現用語から, 出現回数 が上位であった「はちみつのような香り」,「花のよう な香り」,「フルーティーな香り」,「ナッッの香り」を 抽出した。 より詳細な香り評価を行うため,「ナッツ の香り」は「甘いナッッの香り」,「香ばしいナッッの 香り」の 2 項目に分類した.

採点法はすべての対象者に対して行い, TDS 法は, 採点法においてノーズクリップの脱着により嗜好が 変化し, レトロネーザルアロマに敏感と考えられた パネル 47 名のうち, 同意を得られた計 26 名（協力 率 55.3\%）を対象に行った。 TDS 測定にはJ-SEMS. TDS\&TI（株式会社メディア・アイ）のソフトウェア を用い, データの取得はいずれも 1 秒ごとに設定し, 測定上限は 120 秒とした。 なお，TDS 法においては,
その時点で最も印象的であった香りを評価するよう指 示した，食し方は，いずれも噛まずに舐めて評価する ように指示し, 個室ではないが, 独立した静寂な環境 が保たれている空間での評価を実施した.

\section{2-4. 質問紙調查}

対象とした女子大学生の味嗜好の背景を探るため, 上記のパネリストに対して, 官能評価終了後に「食習 慣・食嗜好等に関する質問紙調査」(自記式)を行った. チョコレートに関する項目として, チョコレートはど の程度好きか, 最も好きなチョコレートの種類, 最も 好きなチョコレートの味, チョコレート喫食時に重要 視するもの, 甘いものの契食頻度, チョコレート契食 頻度, チョコレートの食べ方を尋ねた.

その他の食習慣, 食嗜好に関する項目として, 食事 に時間をかけるか, 食べ物の香りを言い当てることが あるか，苦手な食べ物は多いか，自分は甘党だと思う か, 酸味のある食べ物は好きか, ブラックコーヒーは 好きか, 緑茶の渋味は好きかを尋ねた。

加えて, 10 項目 40 種の香りに関し, チョコレート に限定しない一般的な香りの好き嫌いを尋ねた。例示 した香りは, 対象者である女子大生がチョコレートの 言葉だしにより認知していると考えられた,「ロース ト（ココア, コーヒー, カラメル, 焼いたパン)」,「ベ リー (イチゴ, 桃, リンゴ, クランベリー)」,「シト ラス (オレンジ, レモン, グレープフルーツ, ライム)」, 「こく(溶かしバター, キャラメル, はちみつ, 槒油) 」, 「ナッツ (アーモンド, カシューナッツ, ヘーゼルナッ ッ, クルミ)」,「トロピカル (マンゴー, バナナ, パ イナップル, ココナッッ)」,「スパイス (バニラ, シ ナモン, アニス, 生姜)」,「ハーブ (ミント, バジル, ローズマリー, オレガノ)」,「花 (バラ, ラベンダー, スミレ, ユリ)」, 「発酵（青カビチーズ，かつ抢節， 腐葉土, 納豆)」とした.

\section{2-5. 解析方法}

コンピュータの統計データ処理ソフトSPSS Statistics 22.0（日本 IBM）を用いて, 一元配置分散分 析, おょびTukey's HSD 検定, $t$ 検定, Pearsonによ る 2 変量の相関分析, カイ二乗検定を行った。なお, カイ二乗検定において期待度数 5 未満のセルが $20 \%$ 以上であった場合には, Fisher の直接法を採用した。 TDS 法の解析には, J-SEMS, TDS \& TI（株式会社メ ディア・アイ）のソフトウェアを用いた.

調査および官能評価の協力は任意とし，2018 年日 本女子大学倫理委員会 (課題番号 341 号) の承認を得 
Table 2-1 対象者の食習慣・食嗜好（チョコレート に関する項目)

\begin{tabular}{lrr}
\hline & 人 項目 & $(\%)$ \\
\hline チョコレートはどの程度好きですか & & \\
好き & 71 & $(74.7)$ \\
やや好き & 17 & $(17.9)$ \\
普通 & 6 & $(6.3)$ \\
やや嫌い & 1 & $(1.1)$ \\
嫌い & 0 & $(0.0)$ \\
\hline 最も好きなチョコレートの種類はどれですか & \\
ハイカカオ（カカオ分 60\%以上） & 30 & $(31.6)$ \\
ビター & 28 & $(29.5)$ \\
ミルク & 34 & $(35.8)$ \\
ホワイト & 3 & $(3.1)$ \\
\hline
\end{tabular}

$\begin{array}{lrr}\text { 最も好きなチョコレートの味はどれですか } & \\ \text { 苦味のきいたチョコレート } & 44 & (46.8) \\ \text { 酸味のすっきりしたチョコレート } & 6 & (6.4) \\ \text { 甘味の際立つチョコレート } & 42 & (44.7) \\ \text { 渋味を感じるチョコレート } & 2 & (2.1)\end{array}$

チョコレートを食べているときに最も重要視するのは どれですか

$\begin{array}{lrr}\text { 味 } & 76 & (80.0) \\ \text { 香り } & 9 & (9.5) \\ \text { テクスチャー } & 10 & (10.5)\end{array}$

$\begin{array}{lrr}\text { 甘いものをどのくらいの頻度で食べますか } & \\ \text { 毎日 } & 56 & (58.9) \\ \text { 週 3〜5 回 } & 27 & (28.4) \\ \text { 週 1〜2 回 } & 9 & (9.5) \\ \text { 月 1〜2 回 } & 2 & (2.1) \\ \text { ほとんど食べない } & 1 & (1.1)\end{array}$
チョコレートをどのくらいの頻度で食べますか
毎日 14 (14.7)
週 3 5 回 $24 \quad$ (25.3)
週 1 2 回 $37 \quad$ (38.9)
月 $1 \sim 2$ 回 $15 \quad$ (15.8)
ほとんど食べない 5 （5.3）

チョコレートはどのように食べますか

$\begin{array}{lrr}\text { 噛んで食べる } & 58 & (61.1) \\ \text { 舐めて食べる } & 30 & (31.6) \\ \text { その他 } & 7 & (7.3)\end{array}$

Table 2-2 対象者の食習慣・食嗜好（食生活に関す る項目）

\begin{tabular}{|c|c|c|}
\hline 項目 & 人 & $(\%)$ \\
\hline \multicolumn{3}{|c|}{$\begin{array}{l}\text { 普段の食事について，時間をかけてゆっくりと味わう方 } \\
\text { だと思いますか }\end{array}$} \\
\hline 思う & 28 & $(29.8)$ \\
\hline やや思う & 27 & $(28.7)$ \\
\hline 普通 & 20 & $(21.3)$ \\
\hline やや思わない & 14 & $(14.9)$ \\
\hline 思わない & 5 & $(5.3)$ \\
\hline \multicolumn{3}{|c|}{ 漂ってくる食べ物の香りを言い当てることがありますか } \\
\hline よくある & 38 & $(40.4)$ \\
\hline 時々ある & 52 & $(55.3)$ \\
\hline ほとんどない & 4 & $(4.3)$ \\
\hline
\end{tabular}

\begin{tabular}{lrr}
\hline 苦手な食べ物が多いですか & & \\
多い & 20 & $(21.3)$ \\
少ない & 74 & $(78.7)$ \\
\hline 自分は甘党だと思いますか & & \\
思う & 47 & $(50.0)$ \\
やや思う & 21 & $(22.3)$ \\
普通 & 15 & $(16.0)$ \\
やや思わない & 7 & $(7.4)$ \\
思わない & 4 & $(4.3)$ \\
\hline
\end{tabular}

酸味のある食べ物は好きですか

$\begin{array}{lrr}\text { 好き } & 41 & (43.6) \\ \text { やや好き } & 32 & (34.0) \\ \text { 普通 } & 10 & (10.6) \\ \text { やや嫌い } & 9 & (9.6) \\ \text { 嫌い } & 2 & (2.2)\end{array}$

ブラックコーヒーは好きですか

好き $31 \quad 313.0)$

やや好き $17 \quad(18.1)$

普通 7 ( 7.4)

やや嫌い $14 \quad$ (14.9)

嫌い $25 \quad$ (26.6)

\begin{tabular}{lrr} 
緑茶の渋味は好きですか & & \\
好き & 38 & $(40.4)$ \\
やや好き & 23 & $(24.5)$ \\
普通 & 17 & $(18.1)$ \\
やや嫌い & 14 & $(14.9)$ \\
嫌い & 2 & $(2.1)$ \\
\hline
\end{tabular}

未回答者は集計から除外した。 


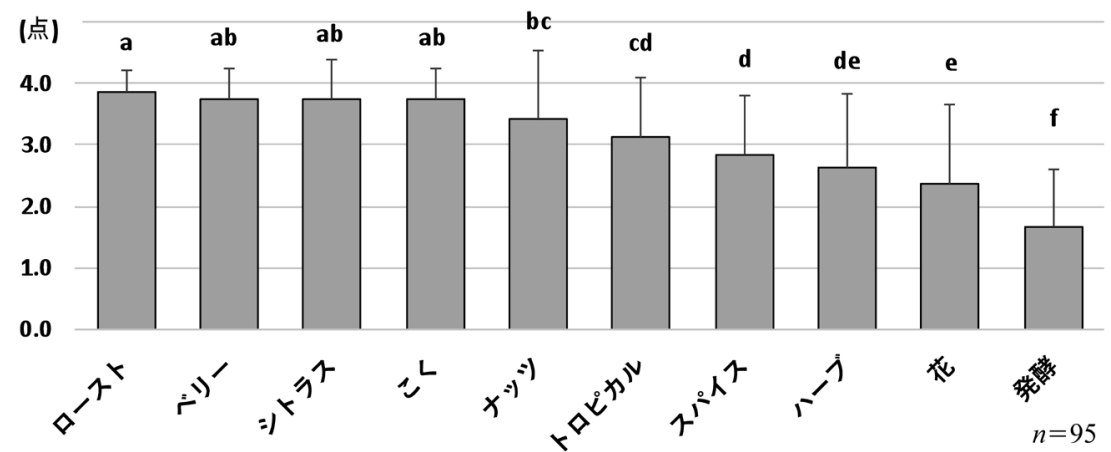

Figure 1 アンケートによる対象者の香り嗜好

10 項目に該当する各 4 種の香りについて好き嫌いを尋ね, 「好き」と回答された選択数を得点とした. 全対象者の平均值を示した，異なるアルファベット間で $p<0.05$ で有意差あり．

たうえ，インフォームドコンセントを行い実施した.

\section{3. 結果と考察}

\section{3-1. 質問紙調查}

質問紙調查は，95 名（有効回答率：100\%）を得る ことができた，対象者の食習慣・食嗜好を Table 2-1, Table 2-2 に示した。「チョコレートはどの程度好きで すか」と尋ねたところ，「好き」が 71 名 $(74.7 \%)$ ，「や や好き」が17名 (17.9\%),「普通」が6名 (6.3\%),「や や嫌い」が 1 名 $(1.1 \%)$ であり，「嫌い」はいなかった， 本研究に打いて, 対象者は扮扮むね, チョコレート好 きであった。

「最も好きなチョコレートの味はどれですか」と尋 ねたところ，「苦味のきいたチョコレート」と答えた 者が 44 名 $(46.8 \%)$ と最も多く,「酸味のすっきりし たチョコレート」は 6 名 (6.4\%),「甘味の際立つチョ コレート」は 42 名 $(44.7 \%)$,「渋味を感じるチョコ レート」は 2 名 $(2.1 \%)$ であり, 対象者のチョコレー 卜嗜好は「苦味好き」と「甘味好き」で二分した。「ブ ラックコーヒーは好きですか」と尋ねた結果において も，「好き/やや好き」と答えた者は 48 名 $(51.1 \%)$ ， 「嫌い/やや嫌い」と答えた者は 39 名 $(41.5 \%)$,「普 通」は 7 名 (7.4\%) であり, 苦味嗜好は二分した. 苦味喏好について, われわれは以前, 苦味成分を含む 6つの食品により検討したところ,「かなり苦味好き /やや苦味好き」と「苦味嫌い」が約半数ずつであっ たことを明らかにしており, 本研究においても, 同様 の結果が得られた（飯田他，2018）.

なお, チョコレートの食べ方について, 本研究では 官能評価時にチョコレートを舐めて評価するよう指示
しているが, 普段のチョコレートの食し方は, 対象者 の $61.1 \%$ が「噛んで食べる」と回答し, 「舐めて食べ る」者は $31.6 \%$ であった。

対象者の香り嗜好の結果を Figure 1 に示した. 10 項目の香りの中で最も高值であったのは「ロースト」 3.9 点であり「ベリー」, 「シトラス」,「こく」も同等 であった。これら 4 種に比べ「トロピカル」,「スパイ ス」,「ハーブ」は有意に低值であった，次いで「花」 2.4 点, 「発酵」 1.7 点であり,「花」および「発酵」の 香りは, 特に嗜好が分かれることが示された。國枝・ 澤野（2002）は匂いに関する感受性について検討し, 「チーズ」の匂いを想起させる $n$-butyric acidに対する 反応が他の匂いと異なり嗜好性が低いことを報告した. 本研究に抢いても「発酵」に関する項目は最低值であ り, 同様と考えられた.

\section{3-2. 採点法による官能評価}

Figure 2 に, 採点法による試料間の官能評価結果 を示した. Figure 2-1に示した通り, レトロネーザル アロマの影響下であるノーズクリップなしの状態で は, 味に関する項目では 4 味㧍よび後味の強さにおい て試料間で有意な差がみられ, ガーナ, ベネズエラは エクアドルに比べ,「甘味」が強く,「酸味」,「苦味」, 「渋味」が弱く,「後味の強さ」が弱いことが示され た。 また，ガーナーベネズエラ間でも有意な差がみら れ, ガーナはベネズエラに比べ,「甘味」が強く,「酸 味」, 「苦味」,「渋味」,「後味の強さ」が弱いことが 示された。「総合評価」に有意な差がみられ, ガーナ, ベネズエラはエクアドルに比べ,「味質の良い」チョ コレートと評価されたことが示された。

Figure 2-2 に示した通り, レトロネーザルアロマの 


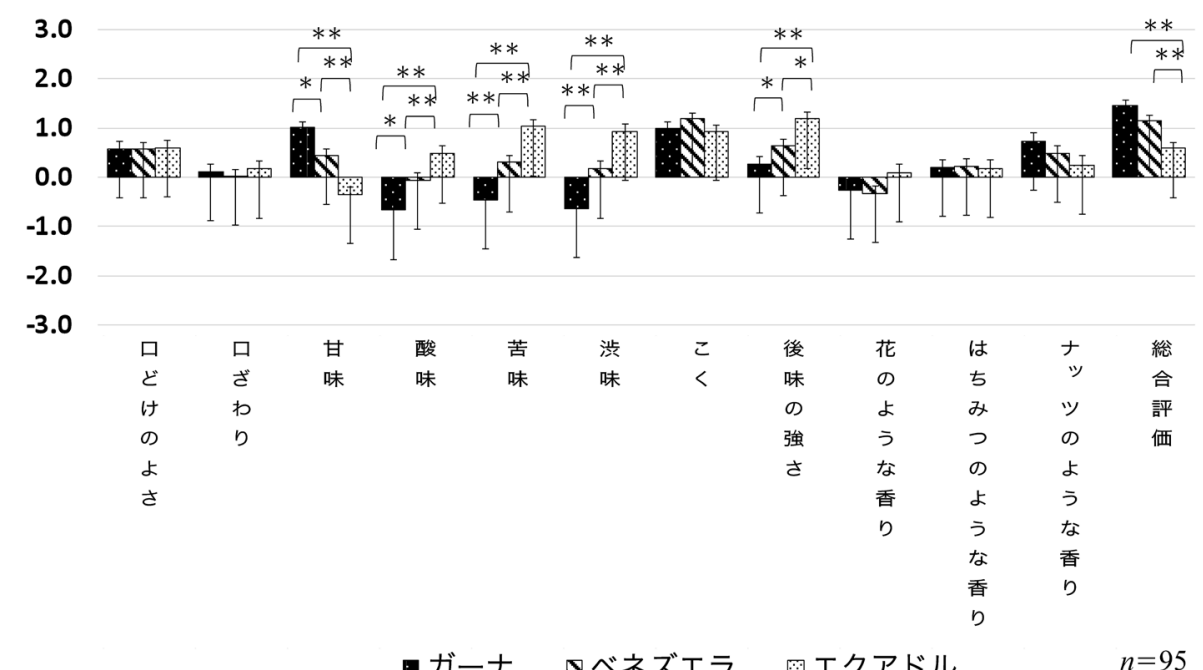

Figure 2-1 3 種のチョコレートの静的官能評価採点法（クリップなし）

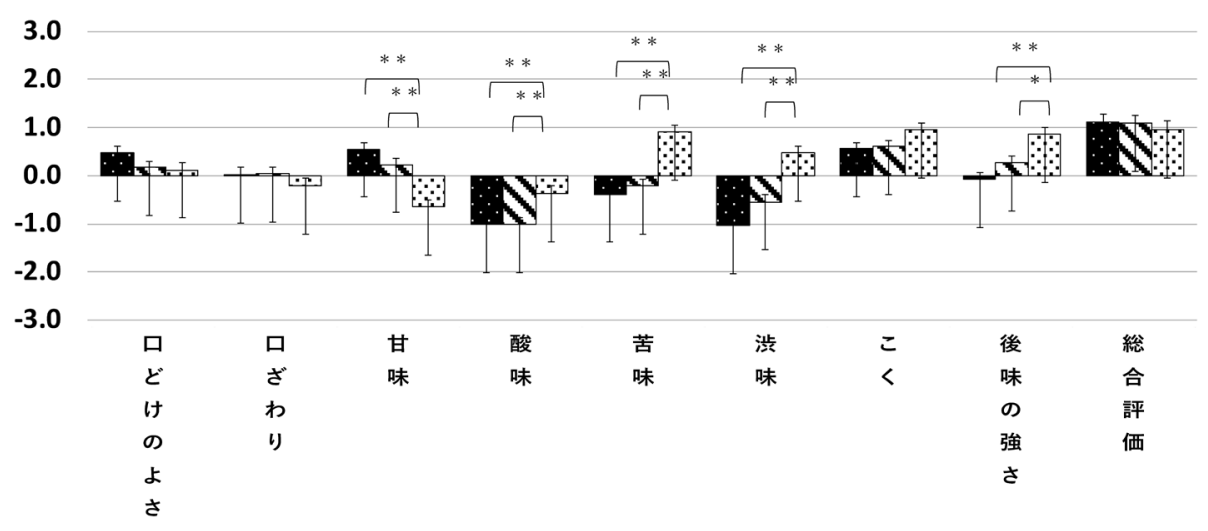

・ガーナ 、ベネズェラ ツェクアドル

$n=95$

Figure 2-2 3 種のチョコレートの静的官能評価採点法（クリップあり） **: $p<0.01 *: p<0.05$

影響を排除したノーズクリップありの条件下では, 4 味および「後味の強さ」において有意な差がみられ, ガーナ, ベネズエラはエクアドルに比べ,「甘味」が 強く,「酸味」,「苦味」,「渋味」,「後味の強さ」が弱 いことが示された，テクスチャーに関する項目，「こ く」,「総合評価」において, 有意な差はみられなかっ た.ノーズクリップなしの際にはみられたガーナ-ベ ネズエラ間において, 有意な差はみられず, レトロ ネーザルアロマの影響下であるノーズクリップなしで はノーズクリップありよりも検出力が上がり，味質の 細かな差異を詳細に評価することが可能であったため
と考えられた.

なお, 三種チョコレートの特性については, 同一配 合のチョコレート, ノーズクリップありの条件下で 行った先行研究 (石川他, 2019, 前揭) において, ガー ナ, ベネズエラはエクアドルに比べ,「甘味」が強く 「苦味」,「渋味」が弱かったことを報告しており, 本 研究はこの結果と同様であった.

全試料において，ノーズクリップ脱着間の差異を 検討した結果を Figure 3 に示した. ノーズクリップ なしではレトロネーザルアロマの影響を排除した ノーズクリップありに比べ,「口どけ」が良く,「甘 


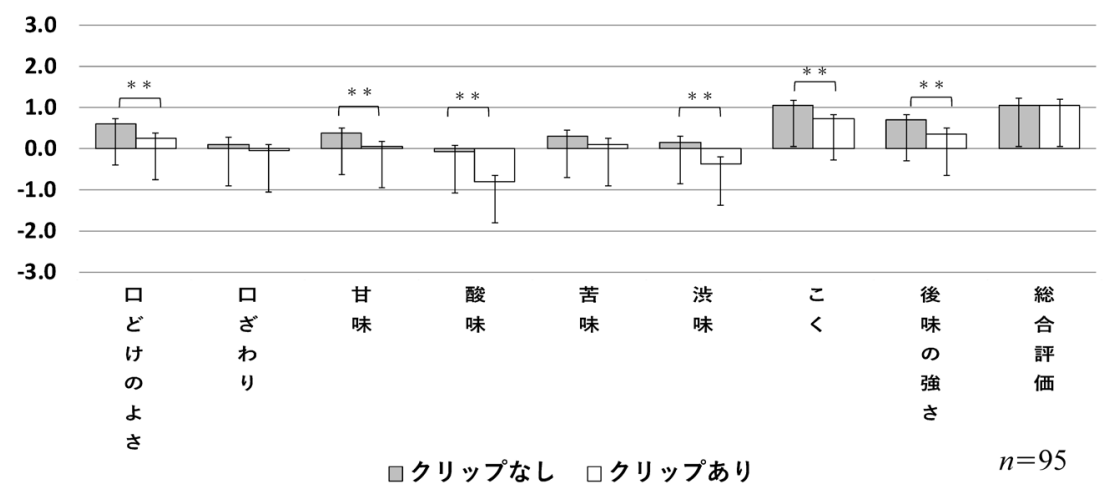

Figure 3 静的官能評価採点法におけるノーズクリップの影響 $* *: p<0.01 \quad(t$ 検定 $)$

味」,「酸味」,「渋味」,「こく」,「後味の強さ」を強く 感じることが示された.「こく」に関して, Nishimura et al.（2016a）は, MSG や IMP な゙のうま味物質が 香りの知覚に扮ける richness と mouthfulnessを増強 することでこく属性に寄与することを報告している. また，熱処理した玉ねぎ濃縮物（heat-treated onion concentrate）の沈殿物が香り物質と相互に作用するこ とによって香り特性の持続が増し, コンソメのこく属 性として香りの持続を誘導することが報告されている (Nishimura et al., 2016b). よって, つまり「こく」は 食品の味, 香りや持続性などが関わる, 複雑な特性で ある.ノーズクリップありの状態ではレトロネーザル アロマの影響が除外されたため, 香りによる刺激も含 む特性である「こく」が低く評価されたと考えられた， Kakutani et al. (2017) は, バニラエッセンスの嗅覚刺 激により，甘味が増強されたことを報告した。ささらに Gotow et al. (2013) は, 鼻腔開放条件では鼻腔閉塞条 件に比べ, 羊羹の甘味, うま味, 塩味の感覚的強度が 増加したこと, 小早川・後藤（2015）は, 羊美に馴染 みのある日本人と馴染みのないドイッ人では味質の感 知のしやすさが異なり, 嗅覚情報に基づく特定の味質 の容易な検知のためには，その食品がどのようなもの かを知っておく必要があることを報告した. 本研究に おいて用いたチョコレートは9割以上の者が「好き／ やや好き」と評価した食品であり, 対象者に馴染みの ある食品である. チョコレートの香りが各味質の感受 性を増強したことが示され, 香りの質も考慮し, 官能 評価を行うことの重要性が示された.

採点法に扔ける項目間の関連を Table 3 に示した. ノーズクリップなしでは,「総合評価」と一部のテク
スチャー, フレーバーに関する項目,「後味の強さ」 を除くすべての味に関する項目に有意な差がみられ, 「口どけ」が良く、「はちみつのような香り」,「ナッツ の香り」が強く, 味においては「甘味」,「こく」が強 く,「酸味」,「苦味」,「渋味」が弱いチョコレートに おいて「総合評価」が高くなることが示された。 ノー ズクリップありでは「総合評価」に対し「口どけの良 さ」,「甘味」,「こく」が正相関であり,「渋味」が負 相関であった．しかしながら，ノーズクリップなしで みられた「酸味」,「苦味」と「総合評価」の負相関は みられなかった。 なお, 本結果は, 「甘味」が強く「苦 味」,「酸味」,「渋味」が弱いチョコレートが高評価と なる先行研究の結果を支持した（石川他, 2019, 前掲). 香り項目と 4 味との間には, 唯一「花のような香り」 において有意な関連がみられ,「酸味」,「苦味」が正 相関であったことから,「花のような香り」が「酸味」, 「苦味」を増強することが示された。 また,「ナッッ の香り」と「こく」との間に有意な正相関がみられ, 「ナッツの香り」が「こく」を増強することが示された.

\section{3-3. TDS 法による官能評価}

TDS 法による香りの経時変化を Figure 4 に示した. ガーナにおいて,「甘いナッッの香り」は急激に増加 し, 10 秒付近で有意水準を上回り, その後減少, 増 加し, 50 秒ごろにピークを迎えた後, 70 秒以降減少 した.「はちみつの香り」は徐々に増加し 35 秒付近で 有意水準を上回ったのち減少, 増加を経て 60 秒, 65 秒付近で再び有意水準を上回った。「花のような香り」, 「フルーティーな香り」,「香ばしいナッッの香り」は 徐々に増加したが, 終始有意水準を下回った. 有意水 準を超えた時間は,「はちみつの香り」11秒,「甘い 
日本官能評価学会誌 Vol. 24 No. 1
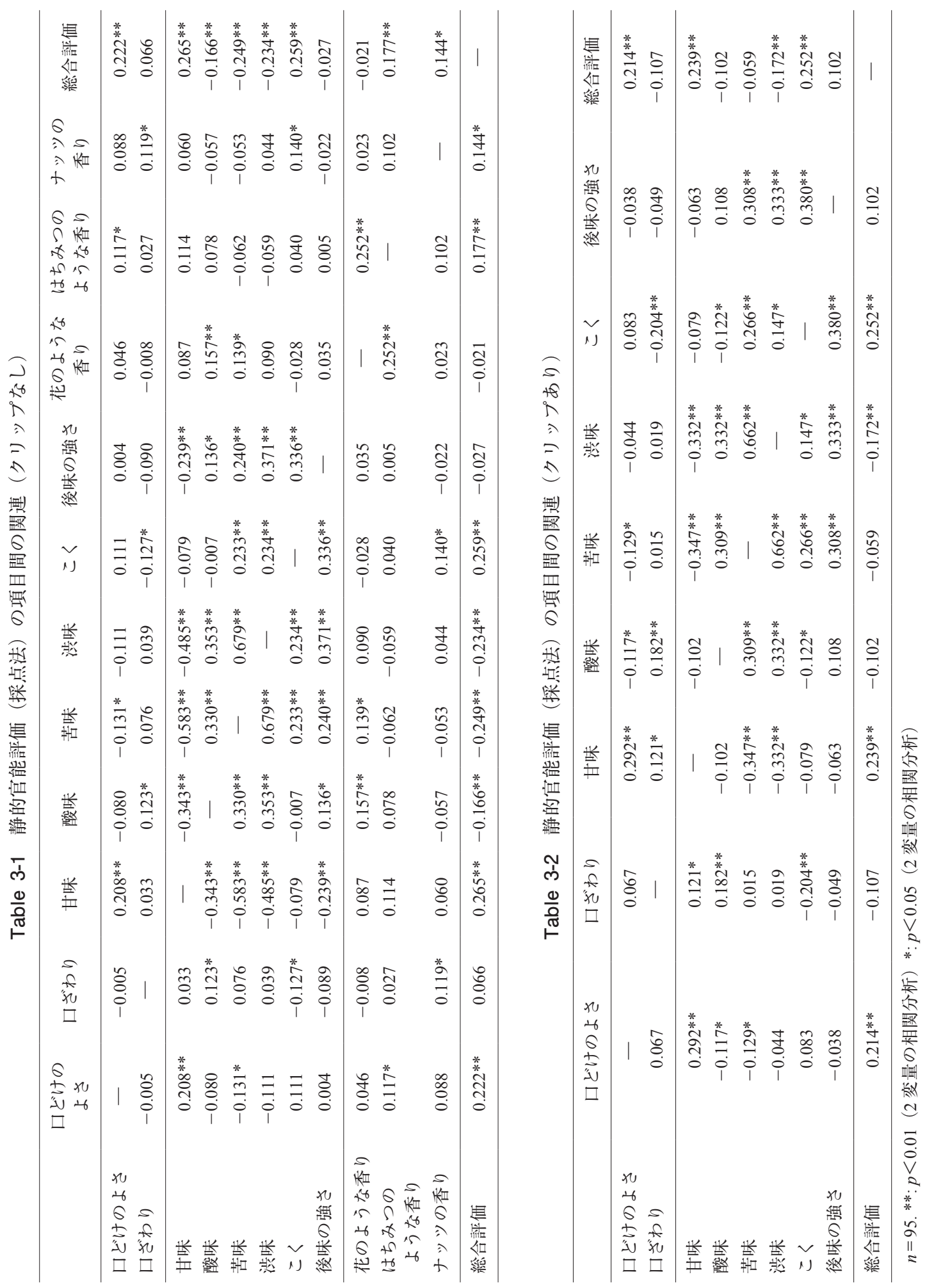

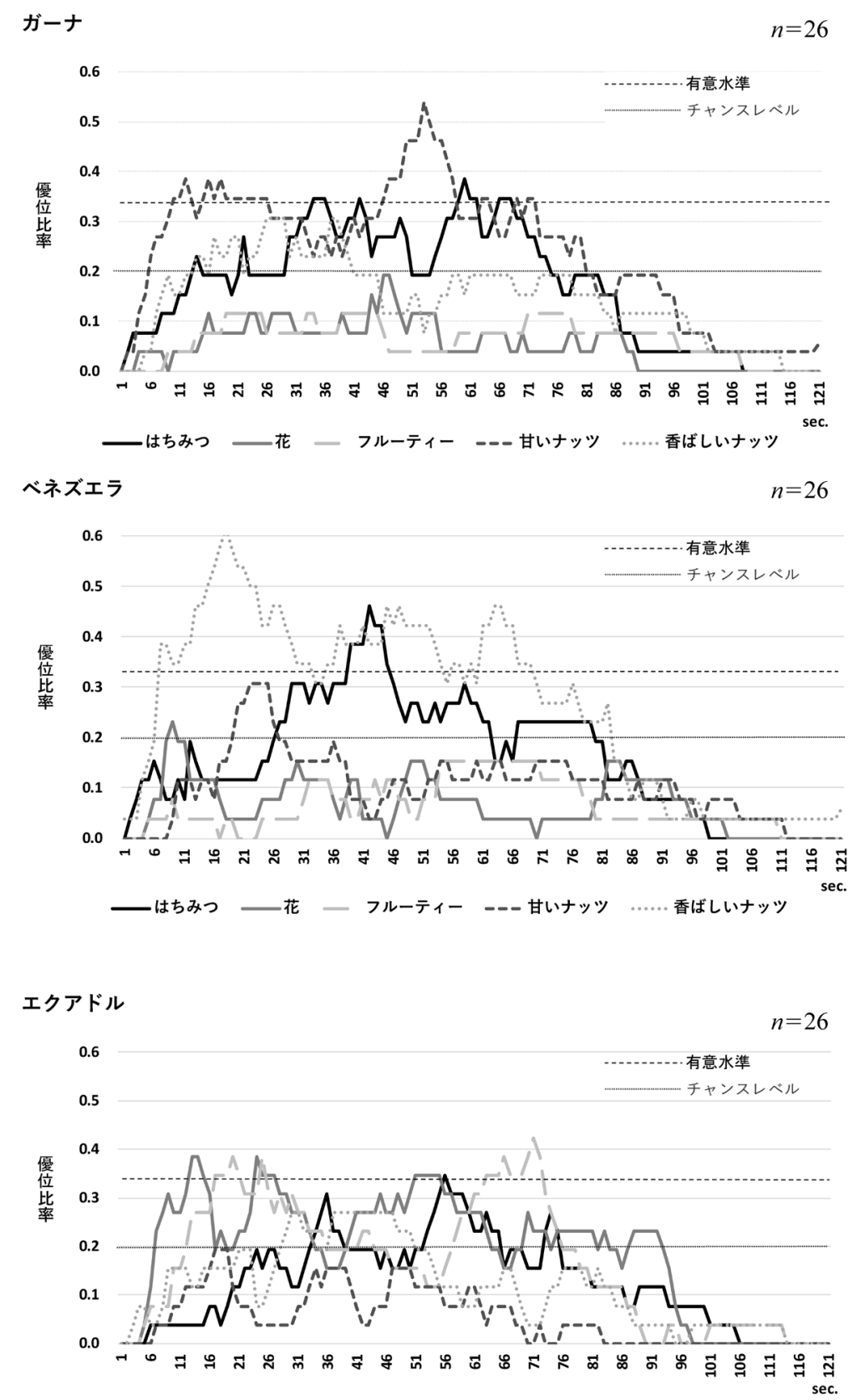

一はちみつ —花 — フルーティー -ーー甘いナッッ ……香ばしいナッッ

Figure 43 種チョコレート香りの TDS 曲線

ナッツの香り」34 秒であり, ガーナは「はちみつの 香り」,「甘いナッツの香り」が特徵であった。

ベネズエラにおいて，「香ばしいナッツの香り」が 急激に増加し，5秒付近で有意水準を上回った。その
後減少, 増加を繰り返すが 70 秒付近までのほとんど の時間において有意水準を上回った。 中盤，40 秒前 後で「はちみつの香り」が有意水準を上回ったが, 45 秒以降急激に減少したのち, 徐々に低下した。「花の 
ような香り」,「フルーティーな香り」,「甘いナッツの 香り」は終始有意水準を下回った。有意水準を超えた 時間は「香ばしいナッッの香り」が 58 秒,「はちみつ の香り」が7秒であり, ベネズエラは「香ばしいナッ ツの香り」が特徵であることが示された.

エクアドルにおいて，「花のような香り」は急激に 増加し 10 秒以降で有意水準を上回ったがその後減増 を繰り返し， 25 秒付近，50秒付近で再び有意水準を 上回った。「フルーティーな香り」は「花のような香 り」の後に増加し, 15 秒付近で有意水準を上回った その後増減し， 60〜70 秒付近にかけて有意水準を上 回った後, 減少した。「はちみつの香り」が 55 秒に おいて, 有意水準を上回った.「甘いナッッの香り」, 「香ばしいナッツの香り」では終始有意水準を下回っ た．有意水準を超えた時間は「花のような香り」 12 秒， 「フルーティーな香り」16秒,「はちみつの香り」 1 秒 であり, エクアドルは「花のような香り」,「フルー ティーな香り」が特徴であることが示された。 これら のことから, TDS 法により従来の採点法では同等と 評価された 3 種のチョコレートの香り特性を詳細に明 らかにし，識別することが可能となった. Braghieri et al. (2016, 前掲) は QDA 法と TDS 法を併用した官能 評価を行い, TDS 法はより詳細な味質の経時変化を測 定できることを報告した。われわれはチョコレートに おいて, 採点法で同等とされた味質が TDS 法ではよ り詳細に特徴づけされたことを明らかにした（石川他， 2019, 前掲). 本研究に扔いても同様の結果が得られ, 香りに抢いても TDS 法により詳細な評価が可能とな ることが明らかとなり, TDS 法の有効性が示された. なお，採点法では統合して尋ねた「ナッッの香り」に ついて, 対象者は「甘いナッツの香り」をガーナ, 「香 ばしいナッツの香り」をべネズエラに特有な香りと回 答しており, これらは異なる特性の香りとして, 明確 に対象者に識別されていることが示された。 なお，今 回, 採点法に抢ける「ナッツの香り」と 4 味の強度と
の間に有意な関連がみられなかった理由として, TDS 法で分けた 2 種の特性の異なる香りを統合したことが 要因と考えられ, 今後は採点法に扔いても項目を分 け, 詳細に検討する必要があろう。 チョコレートの香 気成分に関する先行研究では, 官能評価によるフレー バー特性と GC-O 分析や GC-MS 分析により測定され た香気成分との関連が認められたことが報告されてい る (Owusu et al., 2013; Moreira et al., 2018). また, 佐 川他（2015）により, チョコレートに類似した性質を もつモデル食品の連続的な揮発性成分の測定が Direct analysis in real time mass spectrometry の利用によって可 能であったことが報告されている. 本研究においては, 香気成分の測定は行わなかったが，われわれは，2013 年にカカオマス試料中の香気成分を測定しており, 香 気成分と官能評価結果との主成分分析により，ガーナ， ベネズエラは香りが似ており，5-methyl-2-phenyl-2hexenal「ココアの香り」, 2,3,5-trimethylpyrazine「ナッ ツの香り」, tetramethylpyrazine「麦茶の香り」など香 ばしい香りが特徵とされ, エクアドルは2-pentanol「グ リーンの香り」, 2-phenylethyl alcohol「花の香り」が 特徵とされたことを明らかとした（飯田他，2012）。 本研究の TDS で特徵とされた香りの中には, ガーナ 「甘いナッッの香り」, ベネズエラ「香ばしいナッッ の香り」, エクアドル「花のような香り」が挙げられ， 今後は, 上記の香気成分と本研究で明らかとされた特 徵的な香りとの関連を検討することが望まれよう.

\section{3-4. チョコレートの嗜好変化}

$\lceil 3$ 種のうち最も好きなチョコレートはどれですか」 と尋ねた結果を Table 4 に示した. ノーズクリップな しの状態ではガーナ 55 名, ベネズエラ 24 名, エクア ドル 16 名であった。一方, レトロネーザルアロマの 影響を排除したノーズクリップありの状態では, ガー ナ 38 名, ベネズエラ 27 名, エクアドル 30 名であった ノーズクリップ脱着条件下に扔ける 3 種チョコレー 卜嗜好に有意差がみられ $(p<0.01)$, 残差分析の結果,

Table 4 ノーズクリップ脱着それぞれにおけるチョコレート嗜好

\begin{tabular}{|c|c|c|c|c|}
\hline \multirow{2}{*}{ ノーズクリップなし } & \multicolumn{3}{|c|}{ ノーズクリップあり } & \multirow{2}{*}{$p$ 值 } \\
\hline & ガーナ $(n=38)$ & ベネズエラ $(n=27)$ & エクアドル $\quad(n=30)$ & \\
\hline ガーナ（n=55） & $31(56.4)^{* *}$ & $15(27.3)$ & $9(16.4)^{* *}$ & \\
\hline ベネズエラ（n=24） & $4(16.7)^{* *}$ & $8(33.3)$ & $12(50.0)^{*}$ & 0.001 \\
\hline エクアドル $(n=16)$ & $3(18.8)$ & $4(25.0)$ & $9(56.3)^{*}$ & \\
\hline
\end{tabular}

$p$ 值：カイ二乗検定. **: $p<0.01$ (残差分析) *: $p<0.05$ (残差分析) 


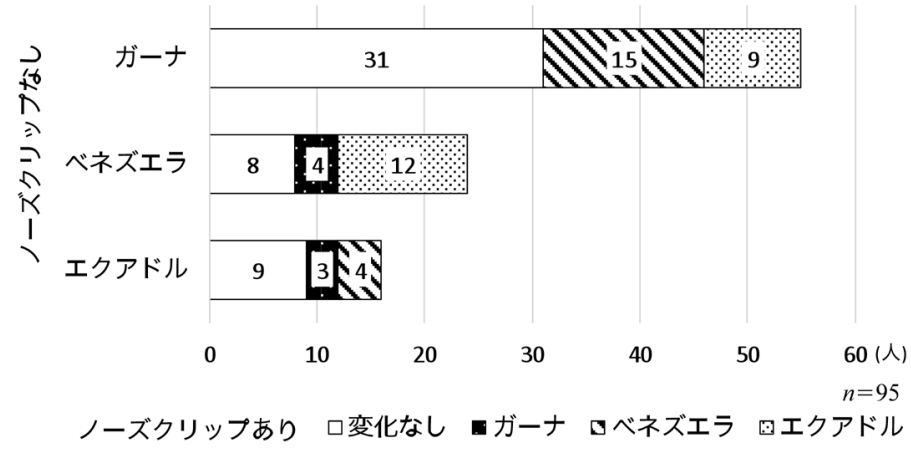

Figure 5 ノーズクリップの脱着によるチョコレート嗜好の変化

ノーズクリップなしで「ガーナ好き」の者は，ノーズ クリップありで「ガーナ好き」が多く「エクアドル好 き」が少ないこと（それぞれ $p<0.01 ）$, ノーズクリッ プなしで「ベネズエラ好き」の者は, ノーズクリップ ありで「ガーナ好き」が少なく「エクアドル好き」が

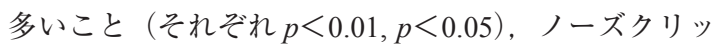
プなしで「エクアドル好き」の者はノーズクリップあ りで「エクアドル好き」が多いことが示された $(p<$ 0.05). 全対象者のうち, ノーズクリップの有無でチョ コレートの嗜好が変化した者は 47 名 $(49.5 \%)$ であ り, 多くの者がレトロネーザルアロマの影響を受け ていることが示された。 なお, Table 2-1に示した通 り, 質問紙調査ではチョコレートを食べているときに 「味」を重視すると答えた者が $80.0 \%$ と最も多く, 「香 り」は 9.5\%であったが, 実態調査である官能評価で は約半数の者が香りの影響を受けていることから, 対 象者は意識レベルでは味を重要視してチョコレートを 食べるにもかかわらず, 官能評価においては意識とし て 9.5\%の者にしか挙がらなかった香りにより， 5 割 もの者の嗜好が変化したことから, 意識と害態との乘 離が明らかとなった。

対象者の嗜好変化の内訳を Figure 5 に示した。なお， 図の横軸の人数がノーズクリップなしで各チョコレー 卜を最も好きと回答した人数を示す.

ノーズクリップの有無で嗜好変化が見られなかった 者の内訳は, ガーナ 31 名, ベネズエラ 8 名, エクア ドル 9 名であった.ノーズクリップの装着により, ベ ネズエラから 4 名, エクアドルから 3 名がガーナに移 行し, ガーナから 15 名, エクアドルから 4 名がベネ ズエラに移行, ガーナから 9 名, ベネズエラから 12 名がエクアドルに移行した。

\section{3-5. 対象者のチョコレート嗜好に関する因子の検討} 対象者のチョコレート嗜好に関する因子を明らかに するために，ノーズクリップなしの際の最も好きな チョコレートの種類と食習慣・食嗜好との関連を検 討した.「苦手な食べ物は多いですか」という問いに 対し「多い」と答えた者はガーナ 17 名 $(31.5 \%)$, ベ ネズエラ 2 名 $(8.3 \%)$, エクアドル 1 名 $(6.3 \%)$ で あったのに対し，「少ない」と答えた者はガーナ 37 名 (68.5\%), ベネズエラ 22 名 $(91.7 \%)$, エクアドル 15 名 $(93.7 \%)$ であり，3 試料間で回答に有意な差がみ られた $(p<0.05)$. 残差分析の結果, ガーナで苦手な 食べ物が「多い」と答えた者の割合が高く，「少ない」 と答えた者の割合が低いことが示された $(p<0.01)$.

「酸味のある食べ物は好きですか」という問いに対 し「好き」と答えた者はガーナ 37 名 $(68.5 \%)$, ベネ ズエラ 21 名 $(87.5 \%)$, エクアドル 15 名 $(93.7 \%)$ で あったのに対し,「普通/嫌い」と答えた者はガーナ 17 名 $(31.5 \%)$, ベネズエラ 3 名 $(12.5 \%)$, エクアド ル 1 名 $(6.3 \%)$ であり，3 試料間で回答に有意な差が みられた $(p<0.05)$. 残差分析の結果, ガーナで「好 き」と答えた者が少なく,「普通／嫌い」と答えた者 の割合が多いことが示された $(p<0.05)$.

なお，「ブラックコーヒーは好きですか」という問 いに対し「好き」と答えた者はガーナ 22 名 (40.7\%)， ベネズエラ 15 名 $(62.5 \%)$, エクアドル 11 名 (68.7\%) であったのに対し,「普通/嫌い」と答えた者はガー ナ 32 名 (59.3\%), ベネズエラ9名 (37.5\%), エクア ドル 5 名 $(31.3 \%)$ であり, ガーナで「好き」と答え た者が少ない傾向であった $(p=0.062)$ 。これらのこ とから, ガーナ好きの者はエクアドル好き, ベネズエ ラ好きの者に比へ酸味や苦味の強い食べ物に対し苦手 意識をもつ者が多く, これが「苦手な食べ物が多い」 
という意識と関連していると考えられた。

「最も好きなチョコレートの種類はどれですか」と いう問いに対し「ハイカカオ／ビター」と答えた者 はガーナ 27 名 $(49.1 \%)$, ベネズエラ 18 名 $(75.0 \%)$, エクアドル 13 名 $(81.2 \%)$ であったのに対し,「ミル ク／ホワイト」と答えた者はガーナ 28 名 (50.9\%), ベネズエラ 6 名 $(25.0 \%)$, エクアドル 3 名 $(18.8 \%)$ であり，3 試料間で回答に有意な差がみられた $(p<$ 0.05). 残差分析の結果, ガーナで「ハイカカオ $/$ ビ ター」と答えた者が少なく,「ミルク／ホワイト」と 答えた者が多いことが示された $(p<0.01)$. 「最も好 きなチョコレートの味はどれですか」と尋ねたところ， 「苦味のきいたチョコレート」と答えた者はガーナ 17 名 $(30.9 \%)$, ベネズエラ 14 名 $(60.9 \%)$, エクアド ル 13 名 $(81.2 \%)$ であったのに対し,「その他」の回 答をした者はガーナ 38 名 $(69.1 \%)$, ベネズエラ 9 名 $(39.1 \%)$ ，エクアドル 3 名 $(18.8 \%)$ であり，3 試料 間で回答に有意な差がみられた $(p<0.01)$. 残差分析 の結果, ガーナで「苦味のきいたチョコレート」と 答えた者が少なく，「その他」を答えた者が多いこと， エクアドルで「苦味のきいたチョコレート」と答えた 者が多く，「その他」を答えた者が少ないことが示さ れた (それぞれ $p<0.01)$. このことから，ガーナ好き では甘味の強いチョコレートを, エクアドル好きでは 苦味の強いチョコレートを志向する者の割合が高いこ とが明らかになり, これは採点法においてガーナは強 い甘味が, エクアドルは強い酸味, 苦味, 渋味が特徴 とされた結果を裏付けるものであった. なお, ベネズ エラ好きの者はガーナとエクアドルの中間的な食嗜好 であった。

3 種チョコレートそれぞれの選択者においてノーズ クリップの脱着によるチョコレート嗜好変化の有無と 食習慣・食嗜好との関連を検討した。 ガーナ選択者 (ノーズクリップなし）において，「最も好きなチョ コレートの種類はどれですか」に対し「ハイカカオ ノビター」と答えた者は「嗜好変化なし」群で 12 名 (38.7\%)，「嗜好変化あり」群で 15 名（62.5\%）に対 し,「ミルク／ホワイト」と答えた者は,「嗜好変化な し」群で 19 名 $(61.3 \%)$,「嗜好変化あり」群で 9 名 (37.5\%) であった.「嗜好変化なし」群では「嗜好変 化あり」群に比べ「ハイカカオ /ビター」と答えた者 の割合が少なく，「ミルク／ホワイト」と答えた者の 割合が多い傾向であった $(p=0.080)$. エクアドル選 択者（ノーズクリップなし）において，「最も好きな
チョコレートの種類はどれですか」に対し「ハイカ カオ／ビター」と答えた者は「嗜好変化なし」群で 9 名 $(100.0 \%)$,「嗜好変化あり」群で 4 名 (57.1\%) に 対し,「ミルク／ホワイト」と答えた者は,「嗜好変化 なし」群で 0 名 $(0.0 \%)$,「嗜好変化あり」群で 3 名 (42.9\%) であった。「嗜好変化なし」群では「嗜好変 化あり」群に比べ「ハイカカオ／ビター」と答えた者 の割合が多く,「ミルク／ホワイト」と答えた者の割 合が少ない傾向がみられた $(p=0.063)$.「最も好きな チョコレートの味はどれですか」に対し「苦味のきい たチョコレート」と答えた者は「嗜好変化なし」群で 9 名 $(100.0 \%)$,「嗜好変化あり」群で 4 名 $(57.1 \%)$ に対し,「その他」を答えた者は,「嗜好変化なし」群 で 0 名 $(0.0 \%)$,「嗜好変化あり」群で 3 名 $(42.9 \%)$ であった.「嗜好変化なし」群では「嗜好変化あり」 群に比べ「苦味のきいたチョコレート」と答えた者の 割合が多く,「その他」を答えた者の割合が少ない傾 向がみられた $(p=0.063)$. なお, ベネズエラ選択者 (ノーズクリップなし) においてノーズクリップの脱 着による嗜好変化と食習慣・食嗜好に関する因子との 間に有意な関連はみられなかった。ガーナにおいては, 特に甘いチョコレートを志向する者の嗜好変化が少な い傾向であり, エクアドルにおいては, 特に苦いチョ コレーを志向する者の嗜好変化が少ない傾向であった. 香りによってチョコレート嗜好が変化した者のうち, TDS 法において「花のような香り」が特徴的であっ たエクアドルについて検討するため, ノーズクリップ なしでエクアドル好きとなった者を「エクアドル香り 志向群」, ノーズクリップありでエクアドル好きだが 香りの影響によりノーズクリップなしでは他に移行し た者を「エクアドル香り回避群」とし, 食嗜好との関 連を検討した。香りにおいて，10 項目の香り嗜好の うち「ベリー」の得点で有意な差がみられ，「エクア ドル香り嗜好群」の平均值 4.0 点に対し「エクアドル 香り回避群」の平均值は 3.7 点であり, 有意に低いこ とが示された。しかしながら, 花（嗜好群 2.7 点, 回 避群 2.3 点）など他項目において, 有意な差はみられ なかった。 また，食習慣・食嗜好とエクアドルの香り 嗜好との間に有意な関連はみられなかった。本研究に おいて対象者の香り嗜好の背景を尋ねる質問が限られ ていたことから, 今後は「花のような香り」を中心と する香り嗜好の背景因子も検討することが望まれよう．

以上より, 対象者のチョコレート嗜好は甘味好き, 苦味好きに分かれ, 3 種チョコレートの嗜好および 
ノーズクリップによる嗜好変化には甘味, 苦味に対す る味嗜好が関連していることが考えられた。また， 3 種チョコレートの香り特性はそれぞれ異なり, ガーナ は「はちみつの香り」,「甘いナッツの香り」が特徵で あり, これらの香りによって「甘味」がより強調され ること, ガーナ好きの者には甘味好き者が多いことが 示された. ベネズエラは「香ばしいナッツの香り」が 特徴であり，これによって「こく」が増強されること が示された. エクアドルは対象者の香り嗜好が二分し た「花のような香り」が特徴であり，これによって「苦 味」が増強されること, エクアドル好きの者には苦味 好きの者が多いことが示された. よって, 同一の配合 割合にもかかわらず, ガーナでは「甘味」, ベネズエ ラでは「こく」, エクアドルでは「苦味」がそれぞれ のカカオ豆由来の特有の香りによって増強され, 対象 者のチョコレート喏好に影響することが示された.

\section{4. 結語}

カカオ豆産地が異なる 3 種 (ガーナ産, ベネズエ ラ産, エクアドル産）のビターチョコレートを用い, ノーズクリップの脱着それぞれの条件下に抏いて採点 法を行いチョコレートの香りの影響を検討するととも に, TDS 法によりチョコレートの香りの特徴を検討 した.

その結果, ノーズクリップなしの条件下で味の強度 が増し，味の識別が鋭敏になることが示された．TDS 法により, ガーナでは「甘いナッツ」,「はちみつのよ うな」香り, ベネズエラでは「香ばしいナッッ」の香 り, エクアドルでは「花」拈よび「フルーティー」が 特徵的であることが示され, 従来の採点法では判別で きなかった香り特性を明らかにした，質問紙調査で はチョコレートを食べる際に「味」を重視する者は $80.0 \%$ ，「香り」は $9.5 \%$ であったにもかかわらず, 対 象者の $49.5 \%$ がレトロネーザルアロマの有無でチョコ レート嗜好が変化した.「花のような香り」と「酸味」, 「苦味」との間に有意な正相関,「ナッツのような香 り」と「こく」との間に有意な正相関がみられ，これ ら特徴的な香りがチョコレートの嗜好に影響する可能 性が示され, 本研究で用いたカカオ豆産地の異なるビ ターチョコレートにおいても, 香りは味嗜好を増強さ せる重要な評価項目であることが明らかとなった。

\section{謝 辞}

本研究を行うにあたり，サンプルをご提供いただき ました株式会社ロッテ中央研究所の皆様, そして, 官 能評価にご協力いただきました皆様に心より感謝申し 上げます。

\section{引用文献}

Braghieri, A., Piazzolla, N., Galgano, F., Condelli, N., Rosa, G.D. and Napolitano, F. (2016) Effect of preservative addition on sensory and dynamic profile of Lucanian dry-sausages assessed by quantitative descriptive analysis and temporal dominance of sensations, Meat Science, 122(12), 68-75.

Glazier, B.D. and Dimick, P. S. (2000) Differentiating the flavor potential of cocoa beans by Geographic origin, American Chemical Society, 754(1), 293-304.

Gotow, N., Kobayashi, T. and Kobayakawa, T. (2013) Retronasal aroma allows feature extraction from taste of a traditional Japanese confection, Flavour (London), 26(2), 1-9.

Hoskin, J.C. (1994) Sensory properties of chocolate and their development, The American Journal of Clinical Nutrition, 60(Suppl), 1068-1070.

飯田文子, 千田麻美子, 葛西真知子, 坂ノ下典正, 桜 井孝治, 上脇達也 (2007) チョコレートの油脂 含量および組成とおいしさの関係, 日本食品科 学工学会誌, 54 (1), 18-25.

飯田文子, 猪飼ゆい, 兼高祥葉 (2018) カカオ豆のロー スト条件とビターチョコレート嗜好の関連性,

日本官能評価学会誌, 22(2), 98-107.

飯田文子, 篠原英里子, 江口 舞, 葛西知子, 奥山知 子, 相原武志 (2012) ビターチョコレートの香り と嗜好の関係について, 一般社団法人日本調理 科学会平成 24 年度大会 (秋田大学) 研究発表要 旨集, 49.

石川友利加, 吉田かな美, 星野覀由美, 飯田文子 （2019）TI・TDS 法によるカカオ豆の異なるビ ターチョコレートの呈味特性, 日本官能評価学 会誌, 23(1), 14-25.

Jinap, S., Dimick, P.S. and Hollender, R. (1995) Flavour evaluation of chocolate formulated from cocoa beans from different countries, Food Control, 6(2), 105-110.

Kakutani, Y., Narumi, T., Kobayakawa, T., Kawai, T., Kusakabe, Y., Kunieda, S. and Wada, Y. (2017) Taste of breath: The temporal order of taste and smell 


\section{日本官能評価学会誌 Vol. 24 No. 1}

synchronized with breathing as a determinant for taste and olfactory integration, Scientific Reports, 7(1), 8922.

葛西真知子, 石川由花, 酒巻旦子, 奥山知子, 芦谷浩 明, 上脇達也, 飯田文子 (2007) 力 力才豆産地 とチョコレートのおいしさとの関係, 日本食品 科学工学会誌, 54(7), 332-338.

國枝里美, 澤野清仁（2002），においに対する感受性 と年齢及び食嗜好との関係, 日本官能評価学会 誌, 6(1), 28-35.

小早川達, 後藤なおみ (2015), 食品の味わいと味覚・ 嗅覚, 日本調理科学会誌, 48(3), 175-179.

Marcano, J., Varela, P., Cunha, L.M. and Fiszman, S. (2015) Relating dynamic perception of reformulated cheese pies to consumers' expectations of satiating ability, Food Research International, 78(12), 369-377.

Moreira, I.M.D.V., Vilela, L.F., Santos, C., Lima, N. and Schwan, R.F. (2018) Volatile compounds and protein profiles analyses of fermented cocoa beans and chocolates from different hybrids cultivated in Brazil, Food Research International, 109(7), 196-203.

鳴海拓志, 谷川智洋, 梶波 崇, 廣瀬通孝 (2010) メ タクッキー一感覚間相互作用を用いた味覚ディ スプレイの検討一, 日本バーチャルリアリティ 学会論文誌, 15(4), 579-588.

Nishimura, T., Goto, S., Miura, K., Takakura, Y., Egusa, A.S. and Wakabayashi, H. (2016a) Umami compounds enhance the intensity of retronasal sensation of aromas from model chicken soups, Food Chemistry, 196, 577-583.

Nishimura, T., Egusa, A.S., Nagao, A., Odahara, T., Sugise, T., Mizoguchi, N. and Nosho, Y. (2016b) Phytosterols in onion contribute to a sensation of lingering of aroma, a koku attribute, Food Chemistry, 192, 724728.

西野由利恵, Dong Wook Kim, Juan Liu, 安藤広志 （2014）香りが感触に与える効果に関する心理物 理学的分析, 日本バーチャルリアリティ学会論 文誌, 19(1), 17-23.

Owusu, M., Petersen, M.A. and Heimdal, H. (2013) Relationship of sensory and instrumental aroma measurements of dark chocolate as influenced by fermentation method, roasting and conching conditions, Journal of Food Science and Technology, 50(5), 909-917.

Pineau, N., Schlich, P., Cordelle, S., Mathonnière, C., Issanchou, S., Imbert, A., Rogeaux, M., Etiévant, P. and Köster, E. (2009) Temporal Dominance of Sensations: Construction of the TDS curves and comparison with time-intensity, Food Quality and Preference, 20(6), 450-455.

Rodrigues, J.F., Souza, V.R., Lima, R.R., Cruz, A.G. and Pinheiro, A.C.M. (2018) Tds of cheese: Implications of analyzing texture and taste simultaneously, Food Research International, 106(4), 1-10.

佐川岳人, 工藤由貴, 西口隆夫, 川向孝知, 坂倉 幹始, 塩田晃久, 星大海, 松本恵子, 渡 辺 淳 (2015), Direct Analysis in Real Time Mass Spectrometry を用いた食品フレーバーリリースの リアルタイム連続分析システムの開発, 日本食 品科学工学会誌, 62(7), 335-340.

White, T.L. and Prescott, J. (2007) Chemosensory crossmodal stroop effects: Congruent odors facilitate taste identification, Chemical Senses, 32(4), 337-341. 